\title{
A new species of the genus Mimosebasmia Pic, 1946 (Coleoptera: Cerambycidae) from Vietnam
}

\author{
Новый вид рода Mimosebasmia Pic, 1946 \\ (Coleoptera: Cerambycidae) из Вьетнама
}

\author{
Alexandr I. Miroshnikov ${ }^{1,2}$ \\ А.И. Мирошников ${ }^{1,2}$
}

\footnotetext{
${ }^{1}$ Russian Entomological Society, Krasnodar, Russia. E-mail: miroshnikov-ai@yandex.ru

2 Sochi National Park, Moskovskaya str., 21, Sochi, Krasnodar region 354002, Russia.

1 Русское энтомологическое общество, Краснодар, Россия

${ }^{2}$ Сочинский национальный парк, ул. Московская, 21, Сочи, Краснодарский край 354002, Россия.
}

KEY WORDS: Coleoptera, Cerambycidae, Cerambycini, Mimosebasmia, new species, Vietnam.

КЛЮЧЕВЫЕ СЛОВА: Coleoptera, Cerambycidae, Cerambycini, Mimosebasmia, новый вид, Вьетнам.

ABSTRACT. A new species, Mimosebasmiafedorenkoi sp.n., is described from Vietnam. Its differences not only from M. purpurea Pic, 1946, but also from members of the genus Gibbocerambyx Pic, 1923 are listed. The structural features of $M$. fedorenkoi sp.n. notably extend the diagnosis of the genus Mimosebasmia Pic, 1946 and increase the morphological similarity of the latter to the genus Gibbocerambyx. In this connection, the taxonomic status of Mimosebasmia requires revision.

PЕЗЮМЕ. Описывается новый вид Mimosebasmia fedorenkoi sp.n. из Вьетнама. Показаны его отличия не только от M. purpurea Pic, 1946, но и от представителей рода Gibbocerambyx Pic, 1923. Отмечено, что особенности строения M. fedorenkoi sp.n. значительно расширяют диагноз рода Mimosebasmia Pic, 1946 и усиливают морфологическое сходство последнего с родом Gibbocerambyx. В связи с этим указана необходимость уточнения таксономического статуса Mimosebasmia при дальнейших исследованиях.

\section{Introduction}

The genus Mimosebasmia Pic, 1946 has hitherto included a single species, M. purpurea Pic, 1946, described from Tonkin (now part of northern Vietnam) [Pic, 1946]. This species is only known to me from the original description and some specimens taken from southern China, Myanmar, Vietnam, Laos, Thailand, and Cambodia. My repeated attempts to relocate the type specimen of $M$. purpurea in the Muséum national d'Histoire naturelle, Paris, France (MNHN), including directly in the Pic Collection, have failed even despite an active help of several colleagues. The type thus seems to be kept in some other place. Moreover, to the best of my knowledge, there seems to be no other publication which would treat this little-known species.
When studying a rich material collected this year in Vietnam, Kon Tum Province, I have discovered a new species of the genus Mimosebasmia which is described in this paper. The holotype of this new species is to be deposited in the Zoological Institute of the Russian Academy of Sciences, St. Petersburg, Russia (ZISP).

\section{Mimosebasmia fedorenkoi Miroshnikov, sp.n.} Figs 1-5

MATERIAL. Holotype $q$ (ZISP), Vietnam, Kon Tum Prov., Kon Plong Distr., Dak Khe River, 1443'20"N / 108 $18^{\circ} 58^{\prime \prime}$, 1030 m, 8.-23.IV.2015, at light, leg. D. Fedorenko.

Paratypes*, $2 \sigma^{7} \sigma^{7} 1$ ( 9 (the author's collection), Vietnam, Da Nang, Bana Mt., 1400 m, 1559'N / 10759'E, V.2015, leg. Toi Nguyen.

DIAGNOSIS. The new species resembles $M$. purpurea, but differs very clearly in many characters, including the slenderer body, the more strongly elongated elytra, the mostly distinctly coarser sculpture and the less strongly developed setation of the pronotum, the clearly less strongly elevated elytra at the very base on the sides of the scutellum, the presence of teeth at their apex, the poorly (not strongly) impressed scutellum, the larger eyes with larger ocelli and a comparatively less deep emargination, the shorter genae, the much less strongly developed antennal tubercles, a distinguished shape of the submentum with a clearly smaller puncturation, the longer and slenderer antennae (at least so in the female), the peculiar shape of the apical external angle of antennomeres 7-10, the absence of a tubercle at the apex of the prosternal process, the slenderer legs, the clearly sparser setation of the elytra, but a noticeably denser setation on the venter which especially strongly obscures the sculpture of the metasternum and visible sternites, as well as the denser

* After completion of the paper, I have received from my colleague, Dr. Evgeny S. Koshkin (Khabarovsk, Russia) several quality photographs of further three specimens, 2 males and 1 female, which belong to Mimosebasmia fedorenkoi sp.n. These are included in the type series, even though the beetles have not reached me yet.

The males, $25 \mathrm{~mm}$ in length, are very similar to the female, but the antennae are barely longer, and the elytra more or less distinctly narrowed from base towards the apex. 


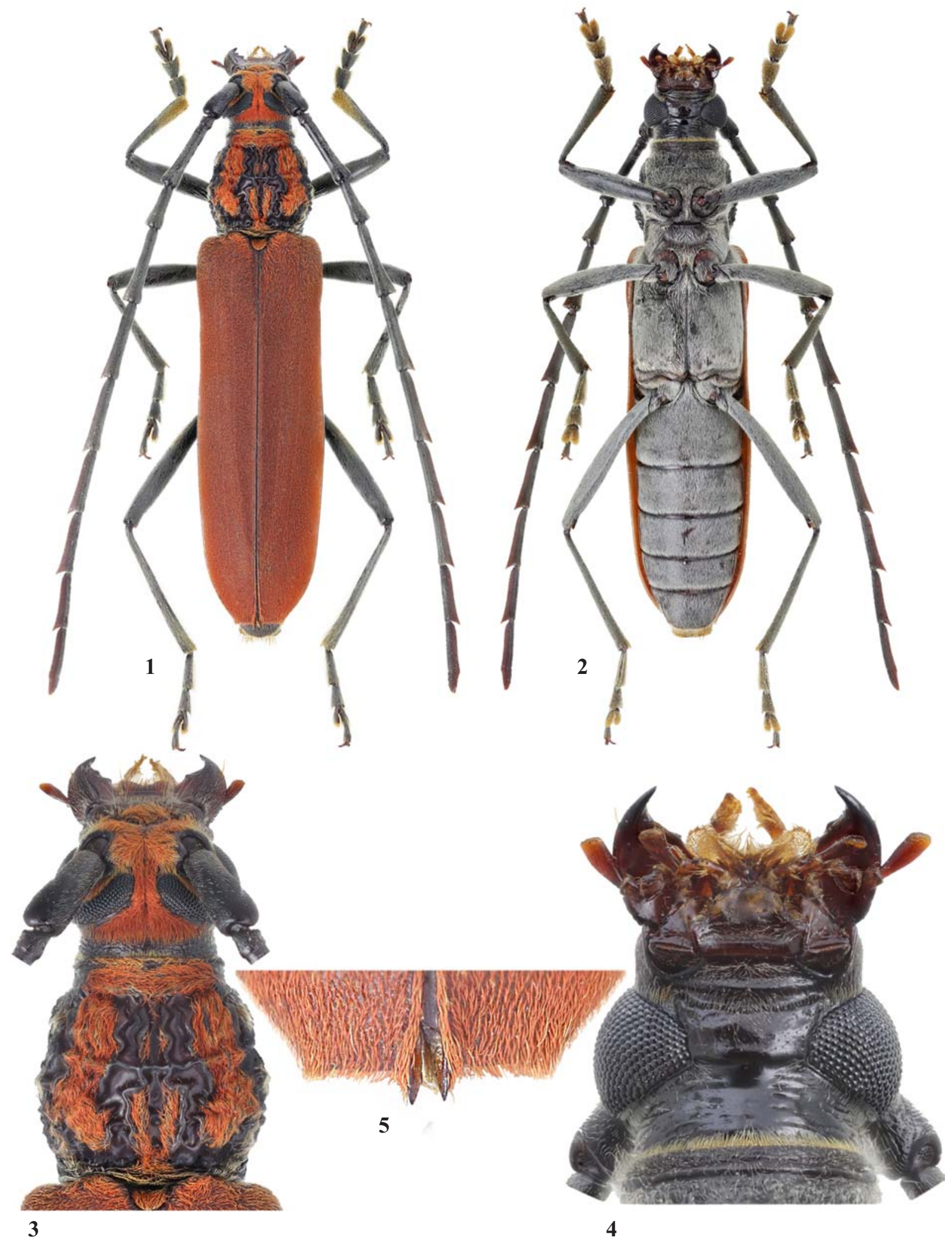

Figs 1-5. Mimosebasmia fedorenkoi sp.n., holotype, female: 1 - habitus, dorsal view; 2 - habitus, ventral view; 3 - head and pronotum, dorsal view; 4 - head, ventral view; 5 - apex of elytra.

Рис. 1-5. Mimosebasmia fedorenkoi sp.n., голотип, самка: 1 - общий вид, сверху; 2 - общий вид, снизу; 3 - голова и переднеспинка, сверху; 4 - голова, снизу; 5 - вершина надкрылий. 
pubescence of the antennae and legs.

The similarity of M. fedorenkoi sp.n. to members of the genus Gibbocerambyx Pic, 1923 is also noteworthy (see Remarks). This, to varying degrees, is strongly shown in habitus, the structure of the antennae, some details of the head, the shape of the pronotum, the character of its sculpture and setation, the structure of the elytra, including their base and the teeth at the apex, the structure of the legs, as well as in a number of the other features. However, it differs clearly from all species of that genus at least by a red coloration of the setation of the dorsum, while from most species it differs in a monochrome (not striped) setation of the elytra. In addition, $M$. fedorenko sp.n., due to a peculiar complex of its characters (except for the above features of setation) described below, is well distinguished from each species of Gibbocerambyx individually.

DESCRIPTION. Female. Body length $23.0 \mathrm{~mm}$, humeral width $5.0 \mathrm{~mm}$. Coloration of integument combines mostly black and red tones; head mainly in area of neck, eyes entirely, antennae mostly, pronotum partly at apex, at base and on coarsely sculptured partitions, scutellum mostly, prosternum partly, meso- and metasterna to a small part, coxae partly, femora and tibiae completely, tarsi almost entirely black; head mostly except for neck, pronotum mainly in spaces between partitions formed by a coarse sculpture, elytra completely except for lighter epipleura, many of antennomeres partly, but most clearly in the area of their apical external angle, venter mostly dark red with this or that colour intensity.

Head with weakly developed antennal tubercles (in $M$. purpurea, these tubercles usually very well-developed); genae about equal in length to last segment of maxillary palpi and much shorter than transverse diameter of eye (in $M$. purpurea, at least in female, genae much longer than last segment of maxillary palpi and about equal in length to transverse diameter of eye); eyes large, rather strongly convex, deeply emarginate, with moderately large ocelli (but clearly larger than in $M$. purpurea); submentum trapezoidal in shape, apex 2.5 times as wide as long in the middle (Fig. 4), with a heterogeneous, irregular puncturation (in $M$. purpurea, submentum apex more than 4 times as wide as long in the middle, with a coarse, irregular, mostly confluent puncturation); antennae noticeably longer than body, extended behind apex of elytra by penultimate antennomere (Figs 1-2) (in M.purpurea, antennae of female usually way or another shorter than body, sometimes only reaching apex of elytra); antennomere 2 barely transverse; length ratio of antennomeres 1-11, 41: 9: 55: 35: 62: 64: 62: 53: 52: 47: 57; apical external angle of apical antennomeres sharpened, most strongly in antennomeres 7-10 (but unlike $M$. purpurea not incurved at the very apex).

Pronotum subequal in length and width near middle, at base 1.26 times as long as width at apex and there with a clear constriction; with a complex, patterned sculpture somewhat resembling that in $M$. purpurea, predominantly very coarse, the most coarse on disk and there forming high partitions, mainly longitudinal, mostly strongly to very strongly sinuous, and a transverse, median, broad, somewhat sinuous and highest partition (Fig. 3); with an almost smooth surface both of partitions proper and spaces between them, only with a gentle microsculpture.

Scutellum longitudinal, at apex rounded, slightly impressed (in $M$. purpurea, scutellum very strongly impressed)

Elytra strongly elongated, 3.44 times as long as humeral width; in basal half about parallel-sided, in apical part mostly slightly narrowed towards apex and only before apex strongly narrowed towards it; at the very base on sides of scutellum clearly, but moderately tuberculiform elevated; apical sutural angle extended into a well-expressed, flattened, almost verti- cally arranged, ensiform tooth, on external side mostly hidden under dense setation, apical external angle forming a short, but clear tooth completely hidden under dense setation dorsally (Fig. 5); with a clear, very dense and confluent puncturation, gradually weakened to apex, forming a finely cellulate, relatively gentle sculpture (in $M$. purpurea, elytra more or less clearly broadened towards apex, in female often broadened more noticeably than in male, but sometimes even in female almost parallel-sided; $2.8-2.93$ times as long as humeral width regardless of sex; at the very base lateral to scutellum tuberculiform, very strongly elevated so that scutellum appearing sunken between these elevations; neither apical sutural nor external angle with a tooth, thereby external angle usually broadly rounded).

Prosternum with a heterogeneous, mostly rough and coarse, predominantly rugose sculpture, thereby in apical one-third mainly with transverse folds, in middle part, before coxae, partly with longitudinal folds; prosternal process very strongly broadened at apex; mesosternal process about 2 times as broad as prosternal process between coxae; metasternum and visible sternites with small, dense punctures, more large ones near the middle suture of metasternum; last (visible) sternite at apex broadly rounded, with a very weak emargination, without impression in apical part.

Legs slender, long; femora not claviform; metatarsomere 1 subequal in length to next two metatarsomeres combined.

Head dorsally in most part, pronotum due to two very broad, longitudinal, paramedian stripes, to two narrow stripes best developed in basal half near middle, and to an apical shortened fascia clothed with dense, recumbent, bright red setae, as in Fig. 3 (in M. purpurea, pronotum mostly with similar setae, but forming no pattern of stripes and fasciae); elytra with same, but much sparser setae barely obscuring puncturation (in $M$. purpurea, elytra clothed with rather dense, recumbent, red setae strongly hiding puncturation); pronotum on sides due to separate spots, venter almost entirely, legs mostly with recumbent, greyish setae, the most dense on metasternum and visible sternites (Fig. 2); protibiae ventrally and on inner side predominantly in apical part, mesoand metatibiae at apex mostly on inner side, as well as tarsi partly with golden yellow setae; long, erect, light setae mainly developed on head, on sides of pronotum and on abdomen apically; the most abundant, erect, but relatively short, light setation covering apical part of prosternum.

REMARKS. Taking into account the structural features of $M$. fedorenkoi sp.n. and, accordingly, the additional new traits which characterize the genus Mimosebasmia, its clear similarity to the genus Gibbocerambyx becomes apparent. In this connection, in the future the taxonomic status of Mimosebasmia seems to require revision.

ETYMOLOGY. The new species honours my colleague and friend, Dr. Dmitry N. Fedorenko (Institute for Problems of Ecology and Evolution, Russian Academy of Sciences, Moscow, Russia), who collected the holotype.

ACKNOWLEDGEMENTS. I am most grateful to Dmitry N. Fedorenko, who was funded by the Russia-Vietnam Tropical Center, for the valuable material he rendered to me for study. My sincere thanks also go to Thierry Deuve and Gérard L. Tavakilian (MNHN) for the opportunity to study the museum material while Denis G. Kasatkin (Rostov-on-Don, Russia) and Francesco Vitali (Luxembourg) provided the specimens of M. purpurea from their private collections. I am deeply indebted to Sergey V. Murzin (Moscow, Russia) who has arranged the receipt of some material for study, to Kirill V. Makarov (Moscow Pedagogical State University, Russia) for his help in the preparation 
of photographs, again to Gérard L. Tavakilian and Sergey V. Murzin for having kindly performed a thorough search for the type of $M$. purpurea in the MNHN collection, as well as to Evgeny S. Koshkin who shared a valuable information.

\section{References}

Pic M. 1946. Coléopterès du globle (suite) // L’Échange. Revue Linnéenne. Ann.62. No.504. P.5-8. 